\title{
Understanding the Constraints of Rural Education for the Conservation of Sea Turtles in La Guajira, Colombia
}

\author{
Ana Maria Martinez \\ York University, Toronto, Canada
}

\begin{abstract}
Recent interviews with fishermen, governmental agency officers and indigenous communities in La Guajira in northern Colombia suggest that local sea turtle populations have declined over the past several years. Possible factors associated with the decline of sea turtles include the Guajiro's view of sea turtle meat as a delicacy, lack of environmental education, ignorance of the law, lack of enforcement of the law, inadequate funding for conservation programs, and the contamination and destruction of local marine and coastal habitats. In recent years, environmental agencies, NGOs and private companies have made efforts working towards sea turtle conservation; however, such initiatives have been largely ineffective. The poor results are a product of the lack of coordination among, investment from, and compromise between CORPOGUAJIRA and the Ministry of the Environment, Housing and Territorial Development. Consequently, the Department of La Guajira has only one ongoing program concerned with sea turtles, one that is generally focused on education but not on conservation.

Successful conservation of a threatened species depends in part on long-term and in-depth population studies. This is particularly true of reptiles, which appear to be extraordinarily vulnerable to global climate change and other human-induced stressors.
\end{abstract}

\section{Introduction}

Colombia started to protect sea turtles by regulating fishing activities in the late 60's and early 70 's. More recently, a greater understanding of the importance of sea turtle habitat preservation has occurred and new approaches have been taken such as erosion prevention and beach protection [7]. Continuous poaching, lack of protection from authorities and the lack of studies on the status of sea turtle population in Colombia means that the future of these populations in Colombia is not promising [34].

In La Guajira, there have been only a few scattered studies. In fact, there has been no monitoring of beaches during a complete nesting season and until now most of the technical data available has been gathered through interviews with fishermen along the coast [6].

One of the first approaches to quantifying the commercial capture of sea turtles in La Guajira -was undertaken in Riohacha in 1988 by RuedaAlmonacid, et al. They recorded the daily arrival of sea turtles to the main "slaughterhouses", which at the same time were widely known restaurants [31].

Traditionally, the people of La Guajira have consumed sea turtle meat as a delicacy for over a century and this gives status to those who serve it. This practice is embedded into their culture to the point that they state that "a breakfast without sea turtle meat is not a real breakfast", a habit they are not willing to give up; even after acknowledging the consequences of continuing to commercialize sea turtles, they remain committed to the idea of it as an endless marine resource. As one of the nonindigenous and "school-educated" interviewees answered when asked: 'What would you do when there are no more sea turtles to eat?' His answer was: 'I will eat then what is available: fish, sea food, etc. Here we have many things.'

Few studies have been undertaken in various parts of La Guajira, using not only different methodologies, but also locations, which has not allowed comparing the results $[3,18,19,21,35]$.

One of the most relevant works was done between June and October of 2002 by INVEMAR (Marine Research Institute "Jose Benito Vives de Andreis"). A characterization of the nesting beaches and foraging areas was carried out for La Guajira (and the rest of the Colombian Caribbean), in which the occurrence of sea turtles was registered based on collected information from environmental agencies, coastal communities and NGOs [21].

In 2006, the MEHTD (Ministry of the Environment, Housing and Territorial Development) used as a baseline a research developed by INVEMAR in 2002 and published a compilation of important nesting and foraging areas of sea turtles in the Colombian Caribbean [26]. That same year, CORPOGUAJIRA (La Guajira's environmental agency, Autonomous Regional Corporation of La Guajira) elaborated a "local management program for the conservation of the sea turtles in the Department” [8].

La Guajira's beaches and vast seagrass beds make an ideal breeding ground for sea turtles, in comparison to the rest of the Colombian Caribbean. 
However, in spite of their biological, ecological, economic and cultural values, not much research has actually been done to date. Various studies had shown that sea turtles' nesting and feeding take place in the area, regardless of the permanent exploitation by the communities. It is necessary to develop a comprehensive study in which education is the main component if the government seeks to adopt measurements to strengthen the protection the remaining populations in the area.

\section{Research Background}

La Guajira is the northern-most department of Colombia. Departments in Colombia are equivalents to Provinces in Canada. Its covers $20,848 \mathrm{~km}^{2}$ and is subdivided into 3 regions, Upper, Mid and Low Guajira (See Figure 1).

From January to April, the climate is hot during the day, but cool and very dry at night. There are two rainy seasons, one with few scattered showers that start at the end of April and May, and the other one with strong but short periods of rain, from October to December. The second dry season is drier than the first one, and the hot winds coming from the Northeast are very strong. This particular rainfall pattern is caused by the geographic position of $\mathrm{La}$ Guajira with respect to the prevailing Northeast Trade Winds [28].

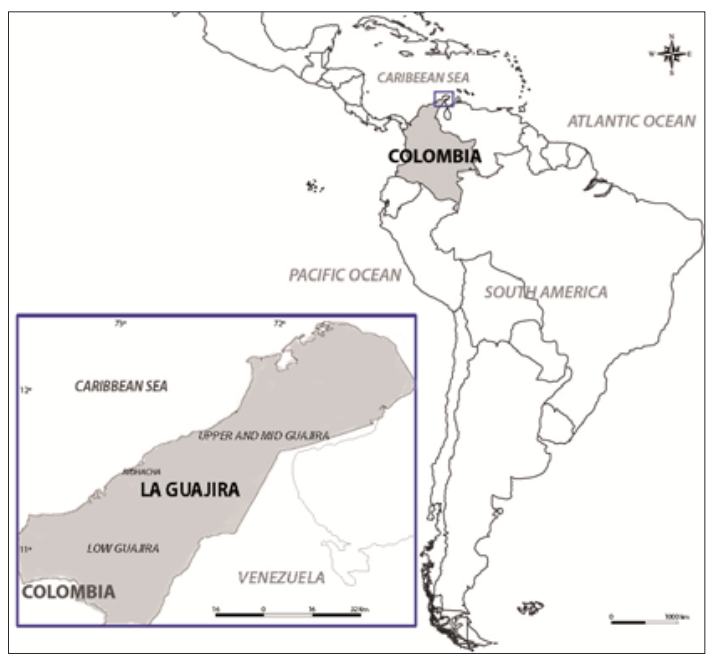

Figure 1. Location of La Guajira, Colombia

The temperature varies from $18^{\circ} \mathrm{C}$ to $45^{\circ} \mathrm{C}$. The dryness increases towards the Upper Guajira, where the water deficit is more pronounced than in the rest of the Department and makes it the most arid region of Colombia, in fact the average annual precipitation is less than $500 \mathrm{~mm}$ per year. In this region, there are just small and intermittent rivers, quite different to the Southern parts of the department; where there are permanent rivers the entire year. Desert environment in many areas of Upper Guajira is increased by the wind speed, which at the same time restricts the agriculture [28].

The continental shelf of La Guajira ends at approximately $80 \mathrm{~m}$ deep [30]. Since this area does not contain river-sediments, the currents determine the sediments distribution in the peninsula [2, 20]. Trade winds are predominant and strong, and "cloudy" shallow waters are enriched by a flow of deep cold waters, making La Guajira an area of high biological productivity and a food web dominated by a benthic component [10, 33].

All the natural physical characteristics of the area, including vast inhabited sandy beaches, winds, temperature (air, water and sand), humidity, etc., directly influence the capacity for the sea turtles to use the nesting areas, and affect the hatching, emergence success and sex ratios of this species [23, 24]. This suggests that the choice for one beach over another is not a random process, but carefully selected where the mother suspects a high reproductive success.

In the Colombian Caribbean, the sea grass and marine algae areas have an approximated extension of 43,219 ha, and La Guajira contains over $80 \%$ of that extension. The mixed seagrass beds belong to the species of Halodule wrightii, Thalassia testudinum and Syringodium filiforme and are distributed from Cabo de la Vela to Riohacha, at a depth ranging between $1 \mathrm{~m}$ to $3 \mathrm{~m}$. Between $3 \mathrm{~m}$ and $4 \mathrm{~m}$ there is a sand strip and then the T. testudinum goes up to $12 \mathrm{~m}$ of depth [4]. The seagrass beds are one the preferred foraging areas for sea turtles. These beds are habitat for many organisms that are part of sea turtles diet, such as crabs, jellyfish and crustaceans, and the sea grass is the main food source for vegetarian species such as the Green Sea Turtle.

Since nest placement is critical for sea turtles, the proximity to tidal zones and supra-littoral vegetation areas is key to their survival [16]. Because of this, and for its strategic location, La Guajira requires special legislation in which the seagrass areas as well as important beaches to be protected [26].

La Guajira is divided into two major areas the Upper and Mid Guajira (which contain the Municipalities of Riohacha, Maicao, Uribia, Manaure, Dibulla y Albania), and the Low Guajira, called the "Province" (which contains the municipalities of Hatonuevo, Barrancas, Fonseca, Distracción, San Juan del Cesar, El Molino, Villanueva, Urumita y La Jagua del Pilar) [11].

In La Guajira, 11 out of 15 municipalities are "Resguardos" and there are a total of 20 "Resguardos" within its limits. Most of the Mid and Upper Guajira correspond to "Resguardos" [29]. A "Resguardo", meaning "guarded area", is an indigenous legally protected area. It has been recognized by the Colombian Government since the early 1980s, and then re-affirmed by the 1991 
Colombian Constitution as collective areas that cannot be sold, traded or handed over by any kind of agreement. Each Resguardo has and follows its own laws and rules [1].

Riohacha, founded in 1535, is the centre of commerce and development and La Guajira was relatively recently declared a Department in 1964. The municipality of Riohacha contains $25 \%$ of the population of La Guajira and it is estimated that by 2015 the population in the Department will exceed 950,000 [11] (See Figure 2).

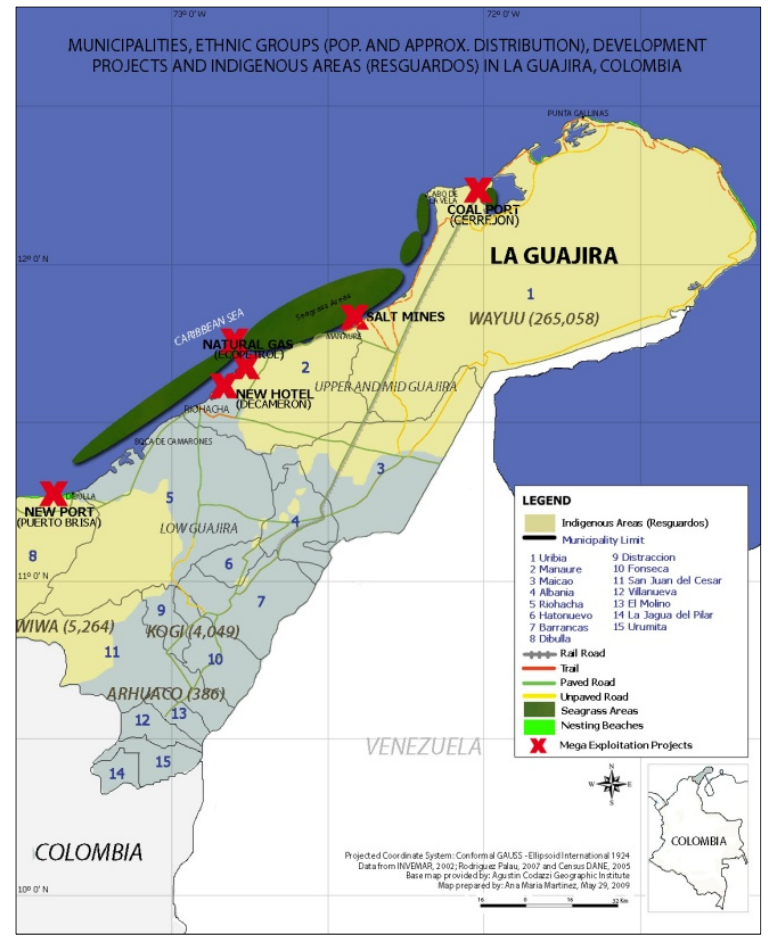

Figure 2. Municipalities, Ethnic Groups (Population and Approximate Distribution), Development Projects and Indigenous Areas (Resguardos) in La Guajira, Colombia

This population growth rate (PGR) is very high (3.14\% between 2010 and 2015), compared to other Colombian coastal Departments, such as Magdalena, where the estimated PGR for the same period of time is $0.95 \%[11,13]$. This has enormous implications for sea turtle populations, under more pressure from the increase in human population and the increase in development projects on the beaches.

The environmental agencies of Colombia work under a decentralized system. The MEHTD defines the guidelines and designs the national frameworks. Then, the Autonomous Regional Corporations (CARs) implement the programs and execute the projects. In La Guajira, the CAR is called CORPOGUAJIRA. All the existing and new development projects must be approved by the MEHTD.

35 interviews were conducted; in total, 52 people were interviewed. The interviewees belonged to
NGOs, CORPOGUAJIRA, MEHTD, the Environmental Police, the Wayuu people (including Traditional Authorities from Uribia, Upper and Mid Guajira), UMATA (Municipal Unit of Technical Assistance on Agriculture), INVEMAR (Marine Research Institute “Jose Benito Vives de Andreis”), National Natural Parks, Fisherman, Mid Traders and non-indigenous Guajiros. An interpreter was hired to translate from Wayuunaiki to Spanish in Punta Gallinas, Taroa and Mayapo.

\section{1. Fishermen (Apaalanchi)}

Limited archaeological research has shown the presence of fishing communities in La Guajira from findings of clay pots in the central part of the peninsula, dated approximately 10 B.C. It seems that the ones who inhabited the Rancheria area, used seasonal traveling to collect fish, molluscs and salt [17].

Different groups during the conquest were recognized and differentiated by the narratives in their chronicles. In the mid 1700s, the main motivation for Spaniards in the zone was pearl extraction, which resulted in the introduction of African and indigenous slaves to the Cabo de la Vela area. The documentary sources revealed the poor conditions and the high levels of exploitation to which the slaves were subjected by the European traders. By the end of the 16th century, indigenous rebellions and a new legal framework abolished indigenous slavery, but the African slavery continued as well as their use for pearl exploitation. By the 17th century, the indigenous people in La Guajira controlled the pearl trade. This allowed them to exchange commodities (guns, cattle and others) with English, Dutch and French. This autonomy defined their social structure and gave them independence before the Spanish Royalty [17].

The word apaalanchi means "beach person", someone who lives next to the sea and depends on it (See Figure 3). Within the Wayuu society, the apaalanchi are seen as the lowest rank, having an unworthy profession. The apaalanchi see themselves as shepherds of the sea: "The Sea is a huge grazing savannah, the sea turtles are cows, the sharks are tigers, the lobsters are hens, and the fish are goats. The ocean is an extensive inexhaustible corral” They consider their richness to be safe in the ocean, while the shepherds are slaves of their animals [17]. 


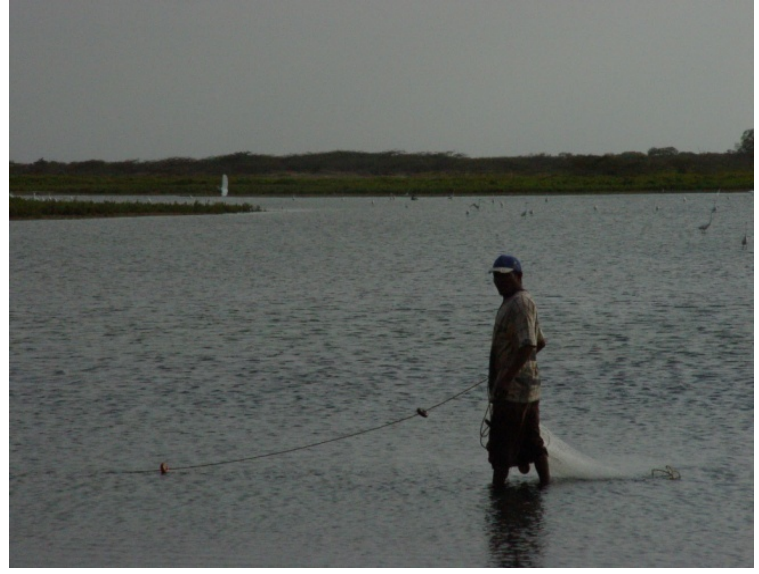

Figure 2. Fisherman, lagoon near Boca de la Raya

The apaalanchi fishing calendar is based upon the movement of constellations, moon phases, winds and rain, as well as social activities, such as funerals, ritual dances, migrations and shamanic prescriptions. They still use small sailing boats and their capacity to move further from the coast is very limited. Their fishing territory is clearly delimited and closed to other apaalanchi or foreign fishermen. They are also expert divers; an apaalanchi who does not know how to dive, is considered incomplete. This practice starts from the childhood, when children go with their fathers to fish. To be initiated into the diving practice, an apaalanchi must "break his ears". After this, it is believed that he would be able to breath underneath the water through them [17].

Unfortunately, there is not much information about this culture and their environmental traditions have barely been explored.

\section{Environmental Education in Colombia}

Interest in environmental education in Colombia is relatively new. Through the Decree 1337 of 1978, the national government stipulated that environmental education was to be implemented in all formal settings, but this stipulation was limited to ecology education without contemplating cultural and economical aspects. Between 1998 and 2002, the ME (Ministry of Environment, replaced by the MEHTD in 2003) designed and tried to implement a program called the "Collective Environmental Project”, which intended to strengthen the educational processes through formal and informal settings and seek outreach to rural and isolated areas within the country. As the government recognizes it, the objectives were too general and created inconsistencies within the agencies, groups and regions, in addition to a lack of coordination of actions between institutions. Additionally, the main concept of 'what the environmental education is for the government' was (and still is) disconnected from the regional issues and the needs of the communities [27].

About 2.23 million Colombians are cannot read and write ( $7 \%$ of the population); in fact $3.6 \%$ of children between 7 and 11 years old do not attend to school [11, 12]. In 2001, La Guajira registered an illiteracy rate of $15.68 \%$ [14].

In 2006, for the first time, an educational decennial plan was formulated. This plan is a collaborative document between the national government and the different sectors of society. This plan establishes guidelines to reach innumerable goals by 2016. Embedded in the objective of education to encourage peace and coexistence, is the environment, but the concept is never developed and is just mentioned in one line of its 284 pages. Additionally, in this document and several others it is mentioned that by law, Colombians are to respect and preserve ethnic and traditional knowledge, but few efforts have been made to get to understand indigenous relationships with their environment, especially in La Guajira [25].

\section{Educational Approaches in La Guajira}

\section{1. Environmental Education Policy}

In urban and rural areas children who attend school do not receive any environmental education (EE) since it is not part of the curriculum in Colombia [25]. In 2006, the Ministry of National Education (MEN), CORPOGUAJIRA and the governor's office made an agreement (\#206 of 2006) called PRAES, in which the government left the responsibility for EE and awareness campaigns to CORPOGUAJIRA, who invested less than 3\% of its approximately US \$32 million annual budget in 2008 towards EE [9].

CORPOGUAJIRA works in two areas, environmental culture and public participation. $33.7 \%$ of the budget was used for environmental culture and included the implementation of the PRAES (a total of 10 in 2008), a meeting of the departmental planning committee for EE (2 in 2008), a meeting of science, education and public participation (4 in 2008), awareness campaigns (14 in 2008), and cultural events (4 in 2008). 66.3\% of the budget was used for public participation which helped to implement public environmental education projects (6 in 2008), which strengthened the formation of community organizations and NGOs (5 in 2008), helped community training on participation mechanisms, developed control and environmental management (800 people in 2008), and supported tree planting projects on low income sites (4 in 2008) [9].

In La Guajira, as in the rest of Colombia, having cultural celebrations, fairs and parties is an essential part of the culture. For this reason, 
CORPOGUAJIRA has created a framework for a series of informal approaches to address sea turtles conservation and education. These mechanisms of involvement and participation are geared towards people of all ages and are used during hatchling release events or when special activities are coordinated with schools, universities, restaurants and organizations such as theatrical representations of the sea turtles problems and solutions. Flyers and pamphlets are distributed to inform the public and a program called "environmental nights" is offered in which the officers from CORPOGUAJIRA visit a community, give lectures and distribute videos. The place where CORPOGUAJIRA has been the most successful is Cabo de la Vela where, according to an officer of the agency the local people do not serve sea turtle. Los Flamencos Fauna and Flora Sanctuary (FFS) has also developed a play in which Wayuu performers who live in the Sanctuary do a performance about the problems of sea turtles and others species.

The only permanent ongoing program is located in Los Flamencos FFS, which in conjunction with CORPOGUAJIRA occasionally teach groups of students and members of the public about sea turtle threats and conservation. Officials release hatchlings just on special occasions or celebrations, once they gather a big audience for the event [8].

\subsection{Access and Infrastructure}

The communities in rural areas in La Guajira certainly have many limitations in attending schools in addition to receiving any type of education. To start with, access is quite complicated since most of the communities live in isolation, the children and teachers have to walk every day great distances to the schools for 1 or 2 hours often under harsh weather conditions. School hours are from 7 a.m. to 3 p.m., therefore some children have to leave their houses around 5 a.m. to reach the school before classes start. This issue is what makes many parents opt for sending their children to boarding schools, many of them Catholics, resulting in traditional values and culture being lost in the process.

The teachers have been providing the lunch and materials for the children since the beginning of 2009, due to a decision made by the Uribia's Mayor Office. In order to decentralize the administration, a NGO was created to manage all resources related to education. The teachers claim that before then, all the resources - including the teacher's salarieswere administered efficiently by the governor's office. In the transition from the former to the new system, the teachers were told that they were not going to receive their first two months of salary. But and addition, the children did not receive their books, materials and food, so the teachers had to start providing them.

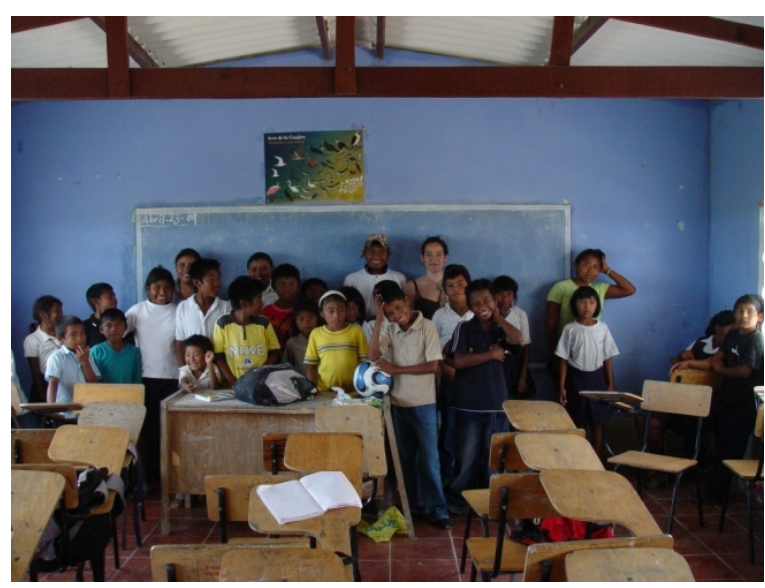

Figure 3. Multigrade classroom in Taroa, Upper Guajira

In the Upper Guajira, most schools have one or two classrooms, each with approximately 30 students from ages ranging from 5 to 16 years old (See Figure 3). Teachers have to juggle the "educational packages" that they are supposed to offer. Some teachers divide the classrooms into two groups, the older children in one and the younger ones in the other. One group has to wait outside while the other group is inside the classroom. The teachers are under paid and the children receive one notebook per school year. Some of the schools have an infrastructure to support several classrooms by are underused by the lack of qualified teachers.

\subsection{Environmental Degradation}

In La Guajira, one of the biggest problems is solid waste disposal. Ironically, waste being one of the most notorious problems in the department, CORPOGUAJIRA carried out only 23 awareness days in 2008 and only used $8 \%$ of its total annual budget [9]. They reported that since the department does not have high levels of industrialization and the urban centres were not too large, contamination in the coastal marine areas does not affect the sea turtle populations, but obviously these statements are made with no supporting scientific evidence [8]. The negative impact of plastic bags and other waste items that end up on the ocean on sea turtles is appalling and has been largely documented. Sea turtles mistake the bags for their natural food causing them to die by suffocation or by blockages to the gut [22, 32]. Not recognizing this as a problem could be the reason why CORPOGUAJIRA allocates such a small amount of resources to this issue. Frazer affirms that some programs could solve a short-term problem, but releasing the turtles into a degraded environment decreases the probability of their survival, so teaching the communities the consequences of the use of resources could lead to positive results [16]. This education process must include local authorities 
who, in most cases, have no knowledge of the local and national regulations. This is demonstrated in a general lack of enforcement by governmental officers and by educators in schools who will eventually need to be updated on current environmental issues so they can pass on the information onto their students.

\subsection{Adults and Informal Education}

In addition, the adult population has no support from any governmental agency to teach them how to improve their life or to explain to them why their practices are wrong. The population in general needs to know the importance of conservation of all resources, not just of sea turtles. Just a little exposure to the problem of sea turtles and other environmental problems through education has demonstrated a shift in behaviour in a community being the most detrimental to sea turtles to being their number one protector. For instance, a worker from Los Flamencos FFS was a sea turtles' fisherman. He was exposed to sea turtles conservation when the park officials were starting the sea turtle's headstarting facilities. He was encouraged to take some park management courses and became one of the facilities' officers in the park. He is currently one of the biggest advocates within his community to save the sea turtles in the area and has positively influence some of the fisherman of the area.

Education through informal settings has been incredibly successful in Colombia. Educating adults about sea turtles would be possible in fairs and community parties, through theatre, dance or another form of art, but it is important to make sure that the message is reaching a large portion of the population.

Through ecotourism it is possible to have an enormous educational impact on the public and on the communities as well as who could directly benefit from such an education. National awareness campaigns should be promoted by the national government and regional programs of cooperation should be established between Colombia and neighbouring countries.

\section{Conclusion}

Colombia requires fundamental changes in its education policy and curriculum, as well as in formal teaching settings in which sustainability is currently far from being conceived as an integral part of the programme. National and local governments need to invest more in education towards the conservation of natural resources, which would at the same time, solve and alleviate other problems such as isolation, poverty, lack of infrastructure and poor access to fundamental basic needs. The government needs to learn to able to teach better practices to a population that has no access to basic education (and is too readily labelled as illiterate).

Even though partnership programs are useful and necessary to reach the goals of EE for sustainable development, it is necessary not just to position ourselves as scientists [5], consumers and teachers, but it is necessary to understand the needs of local people before formulating or implementing a program that has been successful somewhere else. How much ecological literacy is necessary to be taught when a community's only source of income is the selling of sea turtle meat? One way could be to encourage consumers to opt for something else even though when eating these species is an essential part of their culture. Better fishing practices could secure sustainable food sources for those who actually sell sea turtle meat, individuals, eggs, etc. The fishing communities living along the coast do not consume what they fish, unless it has not commercial value. The nutritional deficiencies are enormous and their diet is unbalanced. In any case, fishermen would first starve before consuming one of the captured sea turtles, which represents for them nearly a-month's salary.

The Wayuu people have been neglected by the national government and by non-indigenous Guajiros, and this negligence is being reflected in the rapid loss of their culture, young Wayuu do not want to be associated to their communities. Unfortunately, their environmental traditions have barely been explored, which could explain for instance what is the reason why the apaalanchi (means fisherman in Wayuunaiki) have little or no consciousness of the over use or damaging practices and what is the what are the potentials of biodiversity conservation education in La Guajira? Additionally, such traditional knowledge could indeed help reach what governmental goals have been set to protect sea turtles in the area.

What is evident from the La Guajira's case is that there must be a starting point from which formal and non-formal settings can shift from having no sustainable education at all to a well-designed far reaching educational program focused on sustainability, but at the same time giving special attention to local and regional issues. Currently, we cannot expect to obtain more information about the status of certain wild populations in order to influence in political decisions. It is necessary to recognize that uncertainty is expected even within the most studied populations - especially climate change will transform the life-cycles of many species including that of reptiles.

\section{References}

[1] Acnur. (2006). Los Pueblos Indigenas de Colombia en el Umbral del Nuevo Milenio. Bogota. 
[2] Alvarez-Leon, L., Aguilera-Quiñoñes, J., AndradeAmaya, C., \& Nowak, P. (1995). Caracterización general de la zona de surgencia en La Guajira colombiana. Rev. Acad. Col. Cienc. , 19 (75), 679-694.

[3] Amorocho, D., Cordoba, J., \& Miklin, S. (1999). Current Status of Nesting Sea Turtles in the Northern Colombian Caribbean. Marine Turtle Newsletter (85) , 6-7.

[4] Barrios, L., \& Gómez, D. (2001). Estado de las praderas de pastos marinos. Informe del Estado de los Ambientes Marinos y Costeros en Colombia: Año 2001 , 41-51.

[5] Campbell, L. (2002). Science and Sustainable Use: Views of Marine Turtle Conservation Experts. Ecological Applications , 12 (4), 1229-1246.

[6] Ceballos-Fonseca, C. (2004). Distribución de playas de anidación y áreas de alimentación de tortugas marinas y sus amenazas en el Caribe Colombiano. Bol. Invest. Mar. Cos. (33) , 79-99. Santa Marta, Colombia.

[7] Córdoba, J., De Paula Gutiérrez, F., Rodríguez, C., \& Caicedo, D. (2000, Febrero). Plan de Acción para la Conservación de las Tortugas Marinas del Caribe Colombiano. 85. Ministerio del Medio Ambiente.

[8] Corpoguajira. (2006). Acciones de Manejo Local para la Conservacion de las Tortugas Marinas en el Departamento de la La Guajira. 9. Riohacha.

[9] Informe de Gestion 2008. Riohacha. (2009).

[10] Criales-Hernández, M., Garcia, C., \& Wolff, M. (2006). Flujos de biomasa y estructura de un ecosistema de surgencia tropical en La Guajira, Caribe colombiano. Rev. Biol. Trop. , 54 (4), 1257-1282.

[11] Dane. (2005). Censo Nacional. Retrieved May 30, 2009, from Censo Nacional: www.dane.gov.co

[12] Necesidades Basicas Insatisfechas. Bogota: DANE. (2005).

[13] Síntesis Estadística Semanal. Boletín, Bogotá, D.C.: Oficina de Prensa del DANE, , 18 de Mayo, 2009, 9.

(2009).

[14] Dnp. (2007, June). Documento Regional La Guajira. Agenda Interna para la Productividad y la Competitividad. Bogota.

[15] Eckert, K. (1987). Environmental Unpredictability and Leatherback Sea Turtle (Dermochelys coriacea) Nest Loss. Herpetologica , 43 (3), 315-323.

[16] Frazer, N. (1992). Sea Turtle Conservation and Halfway Technology. Conservation Biology , 6 (2), 179184.

[17] Guerra, W. Los Apaalanchi. Una vision del mar entre los Wayuu. Riohacha: Banco de la República, 2001.

[18] Gutierrez, C., \& Merizalde, L. (2002, Mayo). El Santuario de Fauna y Flora Los Flamencos y las Tortugas
Marinas en La Guajira. Informe Final: Conservacion de Tortugas Marinas en Colombia .

[19] Iavh. (2002, Diciembre 11). Sistema de aprovechamiento sostenible de la tortuga Verde (Chelonia mydas), la tortuga Carey (Eretmochelys imbricata), la tortuga Caguamo (Caretta caretta) y la tortuga Canal (Dermochelys coriacea). 18. (S. Hernandez, Ed.)

[20] Ingeominas. (1998). Geomorfología y aspectos erosivos del litoral Caribe y Pacífico colombiano. Publicacion especial No. $21,114$.

[21] Invemar. (2002, Diciembre). Determinacion de la distribucion y del estado actual de conservacion de las torugas marinas en el Caribe Colombiano. Informe Final: Convenio SECAB - INVEMAR (052-029/01) , 140. (C. Ceballos-Fonseca, Ed.) Santa Marta, Colombia.

[22] McCauley, S., \& Bjorndal, K. (1999). Conservation Implications of Dietary Dilution from Debris Ingestion: Sublethal Effects in Post-Hatchling Loggerhead Sea Turtles. Conservation Biology , 13 (4), 925-929.

[23] McGehee, M. A. (1990). Effects of Moisture on Eggs and Hatchlings of Loggerhead Sea Turtles (Caretta caretta). Herpetologica , 46 (3), 251-258.

[24] Milton, S., Schulman, A., \& Lutz, P. (1997). The Effect of Beach Nourishment with Aragonite versus Silicate Sand on Beach Temperature and Loggerhead Sea Turtle Nesting Success. Journal of Coastal Research , 13 (3), 904-915.

[25] Ministerio de Educacion Nacional. (2006). Plan Decenal de Educación 2006-2016. Pacto Social por la Educación. 284.

[26] Ministerio de Ambiente, Vivienda y Desarrollo Territorial \& Invemar. (2006). Areas de anidacion y de alimentacion de las Tortugas Marinas en el Caribe Colombiano. 79. Bogota, D.C.

[27] Ministerio del Medio Ambiente \& Ministerio de Educacion Nacional. (2002). Política Nacional de Educación Ambiental, SINA. 69. Bogota.

[28] Perez Preciado, A. (1990). Evolucion Paleografica y Dinamica Actual de los Medios Naturales de Peninsula de La Guajira. In G. Ardila, La Guajira. De la memoria al porvenir, una vision antropologica (pp. 23-58). Bogota: Empresa Editorial U.N.

[29] Rodriguez Palau, E. (2007). Colombia: Una nación multicultural. Su diversidad étnica. Dirección de Censos y Demografia. Bogota: DANE, Departamento Administrativo Nacional de Estadisticas.

[30] Romero, A. (2006). Estudio sedimentológico de la plataforma continental de La Guajira entre los 10 y $50 \mathrm{~m}$ de profundidad. Tesis Geologia, Universidad Nacional de Colombia , 96. Bogota.

[31] Rueda-Almonacid, J., Mayorga, J., \& Ulloa, G. (1992). Onservaciones sobre la captura comercial de tortugas marinas en la peninsula de La Guajira, Colombia. 
(INDERENA, Ed.) Contribucion al conocimiento de las tortugas marinas de Colombia , 133-153.

[32] Sea Turtle Foundation. (2009). Marine Debris. Retrieved July 9, 2009, from www.seaturtlefoundation.org

[33] Suzunaga, J., Calero, L., \& Molina, A. (1992). Síntesis del estudio de las condiciones oceanográficas al N-E de La Guajira. Fase II. Boletín Científico C.I.O.H. (11), 59-69.

[34] Villate, R. (2003, Octubre 25-29). Las Tortugas Marinas Capturadas y Comercializadas en los Corregimientos del Cabo de la Vela y Carrizal, Guajira. Memorias del XIII Curso Internacional de Biología y Conservación de Tortugas Marinas . Santa Marta, Colombia.

[35] Widecast, Nfwf, Ministerio del Medio Ambiente \& Uaespnn. (2001, Octubre). Contribucion al conocimiento del estado actual de las tortugas marinas y sus habitas de anidacion en los Parques Nacionales Naturales de la Costa Atlantica. Proyecto "Conservacion de las tortugas marinas en el Caribe Colombiano, NFWF 2001". 